\title{
The Self and the Ontic Trust: Toward Technologies of Care and Meaning
}

Tim Gorichanaz, $\mathrm{PhD}$

gorichanaz@drexel.edu

Accepted for publication in

Journal of Information, Communication \& Ethics in Society

Vol. 17 No. 3 (2019)

Purpose - Contemporary technology has been implicated in the rise of perfectionism, a personality trait that is associated with depression, suicide and other ills. This paper explores how technology can be developed to promote an alternative to perfectionism, which is a selfconstructionist ethic.

Design/methodology/approach - This paper takes the form of a philosophical discussion. A conceptual framework is developed by connecting the literature on perfectionism and personal meaning with discussions in information ethics on the self, the ontic trust and technologies of the self. To illustrate these themes, the example of selfies and self-portraits is discussed.

Findings - The self today must be understood as both individualistic and relational, i.e., hybrid; the trouble is balance. To realize balance, the self should be recognized as part of the ontic trust to which all information organisms and objects belong. Thus technologically-mediated self-care takes on a deeper urgency. The selfie is one example of a technology for self-care that has gone astray (i.e., lost some of its care-conducive aspects), but this can be remedied if selfie-making technology incorporates relevant aspects of self-portraiture. This example provides a path for developing selfconstructionist and meaningful technologies more generally.

Practical implications - Technology development should proceed with self-care and meaning in mind. The comparison of selfies and self-portraits, situated historically and theoretically, provides some guidance in this regard. Some specific avenues for development are presented.

Originality/value - The question of the self has not been much discussed in information ethics. This paper links the self to the ontic trust: the self can be fruitfully understood as an agent within the ontic trust to which we all belong.

Keywords - ontic trust, examined life, virtue ethics, technologies of the self, self-care

\section{Introduction}

The proliferation of networked information technologies brings along myriad issues. One such issue is the rise in perfectionism, which has been called an "epidemic" by one of the leading researchers on the topic (see Baer, 2017). Perfectionism is a personality trait typified by the pursuit of the rare, difficult and flawless, and it has been linked to rising rates of depression and suicide. It is also part of a more general sense of a lack of personal meaning in the modern day (Landau, 2017).

In this paper, I explore how technology can be developed and used to promote an alternative to perfectionism: self-constructionism. Whereas perfectionism focuses on flaws and threats, self-constructionism focuses on 
opportunities to build oneself. To ground this discussion, I develop a framework connecting Luciano Floridi's (2011) model of the informational nature of selfhood to his concept of the ontic trust (Floridi, 2013). The ontic trust suggests that all things are bound together, which implies obligations of care and respect. I show the place of the self within the ontic trust, reminding us all that we also have obligations to care for and respect ourselves. In this way, self-care (an indispensable activity for each self) can be seen as a way of stewarding the ontic trust. Much self-care is done through technology; indeed, it can be said that modern technologies are inherently technologies of self construction. That being the case, care should be taken that new technologies contribute to self-care and meaning, rather than the disregard or even abnegation of the self.

To illustrate a path toward developing such technologies, in the final section of this paper I discuss the example of self-portraiture and selfie-making. Selfie-making has been purported to democratize the centuries-long artistic tradition of self-portraiture, but selfie-making does not seem to be as personally meaningful or as conducive to self-care as self-portraiture is. To begin, the next section explores the crisis of meaning and the role of contemporary information technology therein.

\section{Perfectionism and the Crisis of Meaning}

Most animals seek pleasure and avoid pain, but humans do this and more: We seek things like happiness, satisfaction and prosperity. According to Roy Baumeister (1991), these things depend on meaning, which is distinctly human. In this context, meaning is a matter of having a purpose, experiencing efficacy, and valuing relevant factors as good or bad. Baumeister (2005) argues that meaning in this sense is necessary for human well-being; as humans, we must set goals and achieve them on an ongoing basis.

But the drive for meaning can get sidetracked, such as by perfectionism. This is a personality trait typified by a person's pursuit of the rare, difficult and flawless. While some psychologists have pointed out that perfectionism may be adaptive in that it motivates a person to set and achieve goals (Hamachek, 1978), many argue that the negative aspects outweigh the positive (Flett \& Hewitt, 2002). In particular, recent literature has focused on how perfectionism can lead a person to conclude that any flaws in their achievements or in themselves make their life meaningless (Landau, 2017; Smith, 2017; Storr, 2018). Landau (2017, p. 35) puts it this way:

Perfectionists believe that if our city is not the most beautiful in the world, it is disgustingly ugly; that if one is not Einstein one is a fool; and that if a person does not write like Shakespeare did, she had better just give up writing altogether.

In this maladaptive form, perfectionism has been connected to mental health concerns. A meta-analysis of the research on perfectionism suggests that 
trait perfectionism is associated with suicide ideation and attempts (Smith et al., 2018). A recent longitudinal study, reporting on data from 1989 to 2016, shows that perfectionism has been increasing over the past few decades (Curran \& Hill, 2018). Moreover, rates of suicide and depression have been on the rise for the past several decades in the United States and other developed countries (Centers for Disease Control and Prevention, 2012; Murphy et al., 2017). It has been suggested that a lack of meaning is a key factor in these issues (Oishi \& Diener, 2014); in the context of the present discussion, we can understand perfectionism as part of this bigger picture-which some have dubbed a "crisis of meaning" (see Smith, 2017)-one that is becoming ever more urgent to address.

Modern networked technologies seem to have played a role in this trend toward perfectionism and the crisis of meaning. On social media, people are pressured to appear successful, beautiful, adventurous, etc.; and, seeing such content in endless streams, people experience dissonance and dissatisfaction when their own lives do not seem to be as good as other people's (Curran \& Hill, 2018; Hellmann, 2016; Saunders \& Eaton, 2018). In our globalized society, perfectionists must now compete with a far wider field. Speaking to the crisis of meaning more generally, others have discussed how people today, beset by information overload and enthralled by on-demand culture, feel distracted and unable to engage deeply with the world (Lanier, 2018; Pentina \& Tarafdar, 2014). A review of the empirical literature on social networking sites and psychological well-being by Erfani and Abedin (2018) shows that, while studies reporting on such negative effects constitute a minority of the literature, such findings have been validated.

How can we move forward? To be sure, this is a complex issue, embedded in many social structures. Change, if it is to come, must come through the coordination of many different agents, including designers, business owners, policymakers, etc. But individuals are not simply doomed to be driftwood, tossed about in a stormy sea. Rather, they can take certain actions to counteract, at least partially, the crisis-to find meaning in their lives. This assertion is supported in the psychological literature, which has shown that cultivating meaning can alleviate depression (Reker \& Wong, 1988) and in fact lead to positive well-being (García-Alandete, 2015). The role of technology in one's finding meaning and cultivating well-being is the subject of the following sections. But this is not just a matter of polishing monads; further on, it will be argued that finding personal meaning-caring for the self-is also a matter of caring for society, and indeed for the whole world.

\section{Self-Care and the Ontic Trust: An Alternative to Perfectionism}

An alternative to perfectionism can be found in constructionist ethics. Indeed, psychological treatment for perfectionism (see Hewitt, Flett \& Mikail, 2017) essentially involves adopting such an ethics. Whereas perfectionism focuses on 
threats to perfection, constructionism focuses on opportunities for growth. In constructionist ethics, people are conceptualized as works in progress whose mission is to get better little by little. The perfectionist self, on the other hand, forgets that it can build. This macroethical theory reaches back to Socrates.

At age 71, Socrates found himself on trial, slated to be put to death for corrupting the youth of Athens. With apparent magnanimity, he was given the opportunity to go free if only he would stop doing philosophy. But Socrates would rather die, which he expressed in some of his most famous words: "I say that it is the greatest good for a man to discuss virtue every day [...] for the unexamined life is not worth living" (Plato, 2002, p. 41; Apology, 38a). For Socrates, an ethical life was one of discussion and critical thinking, even if this led to difficult conclusions. This was a means of cultivating virtue (the most fundamental of which, for Socrates, was knowledge) in order to improve oneself and one's world (Parry, 2014).

We are familiar with the ethical injunction know thyself. But Socrates' philosophy reveals another maxim: care for thyself. Though today this phrase is all but forgotten, in Antiquity it was a central rule for living (Foucault, 1988). Indeed, whereas philosophy today is characterized by abstract, intellectual argumentation, philosophy in ancient times was a matter of living life in the best way possible and discovering how to do so through the cultivation (care) of the self (Hadot, 1995).

Such is the approach of virtue ethics, which assumes that if one cultivates oneself, then that goodness will percolate outwards, creating a good society and world. Even if this approach worked in ancient Athens, it may not work in today's societies, with modern information and communication technologies, complex political arrangements and diffuse boundaries. But, as Luciano Floridi (2013, pp. 166-168) argues, this does not mean that the constructionist ethics should be abandoned. Rather, it must shift from ego-poiesis (construction of the self, or ego) to eco-poiesis (construction of the whole information environment, including both agents and patients).

\section{Self-Care and Being Informed}

The move toward eco-poiesis requires an account of how individual selves fit in society. As Floridi writes, a self can be considered as a three-tiered encapsulation of something from its environment: first a biological encapsulation, then cognitive, then conscious (Floridi 2013, pp. 217-220). The biological encapsulation is formed by chemical bonds; the cognitive by perceptual information processing; and the conscious by semantic bonds of narrative and self-awareness. These three layers, to be sure, interact; through the conscious layer, for example, the one's sense of their biological encapsulation be extended to objects beyond the body.

All these layers can change. For instance, practicing meditation (a popular practice of self-care today) may result in changes at each layer (equanimity, longer attention span, lower blood pressure, etc.). The pattern of the biological 
encapsulation is more or less fixed, but not entirely-one does not cultivate oneself by growing to be 20 feet tall, and rarely do people lop off their own limbs, to be sure, though certainly natural and intentional body modifications take place over the course of one's life. The cognitive layer can grow to a greater extent; through training, practice and perseverance, one can increase their capacities for making perceptual judgments in contexts that matter to that person. And the conscious layer is most changeable of all; through relationships, valuation, story and reflection, this aspect of the self can be nurtured and grow endlessly. At the cognitive and conscious layers the self can grow most because here it is perpetually incomplete, projecting itself toward ever-further goals, as Baumeister (2005) has it.

So caring for oneself (on the conscious layer) can be seen as a matter of discovering and cultivating values, coming to love particular people and things, and caring about these values, people and things (Wright, 2016). Indeed, this is the depth of what it must mean for a person to "be informed." In everyday parlance, we say someone is "informed" if they were exposed to some fact and hereafter have knowledge of that fact. But on a more fundamental level, being informed can refer to someone's or something's being formed or having-beenformed through information. (If to be informed is to know, then we can see a suggestion of this depth in the Biblical sense of the verb to know.) To be sure, this sense of being informed involves engaging with those aspects of the world that we don't typically consider informational, but it also involves practices that are readily seen as informational, such as seeking and applying information on particular topics. It also involves technologically-supported self-care, which is discussed below.

\section{The Ontic Trust}

The self should not be understood atomistically; indeed, the very concept of the self is only necessary in social contexts. Consonantly, self-care is not a matter of solipsism. On the contrary, as Pierre Hadot (1995) discusses, self-care is a path to ultimately transcending the self, to seeing oneself as belonging "both to the whole constituted by the human community, and to that constituted by the cosmic whole" (Hadot, 1995, p. 208). Here he quotes Seneca, who wrote of "plunging oneself into the totality of the world" (Letter 66, 6; translation by Hadot). As Hadot writes, this is accomplished by a form of looking inward that also looks outward-in which a person experiences themselves as connected to everything else, leading to a shift in perspective: experiencing life sub specie ceternitatis.

There is a link, then, between self and world. In my view, this can be conceptualized through Floridi's (2013) concept of the ontic trust. This concept was named after the legal concept of the trust, in which one party (the trustor) settles some property on a second party (the trustee) for the benefit of a third party (the beneficiary). Here no one fully owns the property: The trustee is the legal owner of the property, but they do not benefit from it; rather, they are a fiduciary, obligated 
to care for the property on behalf of the beneficiary, who is only an equitable owner of the property. The ontic trust (ontic here meaning roughly "that which exists"), then, is such a relationship wherein the whole world (including all agents and patients) is the property, owned by no one but passed down by past generations (donors) and cared for by current agents (trustees), for the benefit of all future and current patients and agents (beneficiaries). Thus the ontic trust is a "primeval, entirely hypothetical pact, logically predating the social contract, that all [...] agents cannot help but sign when they come into existence, and that is constantly renewed in successive generations" (Floridi, 2013, p. 301).

As that quotation implies, Floridi intends the ontic trust to be an update to social contract theory. The social contract is an implicit agreement among people to cooperate, making some sacrifices in order to reap the benefits of social life; the absence of such a contract would make life "solitary, poor, nasty, brutish and short," as Hobbes (1651, p. 78) famously wrote. The social contract as theorized by Hobbes and subsequent thinkers does not arise naturally, but rather is contingent on others' accepting the contract, and it cannot account for moral action toward others who have no claim on us, such as future generations and nonhuman animals (Rachels \& Rachels, 2015). Floridi's (2013) concept of the ontic trust overcomes these limitations. The ontic trust, as Floridi writes, is entered unwillingly and inescapably, but it is not coercive; rather, it constitutes a caring bond, an invitation to respect and appreciate others (including other people and all organisms and things), "which is fostered by the recognition of the dependence of all entities on each other" (Floridi, 2013, p. 302). The ontic trust suggests that all beings and things are bound to each other by their very fact of existing, which implies obligations of care and respect.

The concept of the ontic trust has proven relevant and inspirational to thinkers in library and information science, which is concerned with "the activity of stewardship of the semantic environment" (Floridi, 2004, p. 662). Richard Fyffe (2015) writes in support of the ontic trust concept in the context of librarianship. For example, librarians are concerned with long-term preservation, and justification for such preservation is apparent in the ontic trust, as future generations (and their information needs) are given moral worth. Fyffe also gives additional support to the notion that all information objects deserve (at least minimal) moral respect.

We do not know to what causal chains, or to what chains of evidence and reasoning, we owe our existence or our current knowledge. A kind of moral prudence would urge at least minimal respect for any object or knowledgeclaim, lest we disrespect that which made us (or our current knowledge) possible in the first place. Floridi's argument may serve as a version of John Rawls's "veil of ignorance." (Fyffe, 2015, p. 279)

Van der Veer Martens (2017) elaborates on Fyffe's discussion, offering broader conceptual and historical context, and Bawden and Robinson (2018) build further on this as part of an argument in support of adopting Floridi's philosophy and 
ethics of information as a foundational philosophy in library and information science. What has not yet been identified or explored is the fundamental role of individual selves in maintaining the ontic trust, and that is what I will focus on here.

Under Floridi's (2013) postulation of the ontic trust, all beings have obligations toward each other and even toward being as such. Selves, as conceptualized above, are also information objects and should therefore be subjects of stewardship. This can occur at any of the three layers of selfhood: Simplifying for illustration, we can say that physical therapists (for example) chiefly care for the biological layer of selves; teachers for the cognitive one; and loved ones for the conscious. Selves are clusters of experience-we are all little corners of the universe. As participants in the ontic trust, we can see that we must take care of ourselves because that is tantamount to taking care of the universe.

So we have an obligation to care for ourselves, but of course we must likewise help others to care for their own selves. Good physical therapists, teachers and lovers-to say nothing of librarians and other information professionals-do this as well. Ontic trustees show you that, no, you are not perfect, but that is no cause for agony; you can continually build and better yourself, and indeed you ought to. At root, this is the recognition that all beings are connected, but that certain actions must be directed by agents toward themselves for the subsequent betterment of all. In the next section, I discuss the role of technology in this sort of self-care.

\section{Technologies of the Self}

It is perhaps an understatement to say that modern information and communication technologies (ICTs) play a major role in how we construct and conceptualize ourselves and our relationships. Both Mazlish (1993) and Floridi (2013) have suggested that the concept of information signals a fourth revolution in our understanding of humanity (after the discoveries of heliocentrism, natural selection, and the subconscious). In the words of Floridi, ICTs are inherently "technologies of self construction, significantly affecting who we are, who we think we are, who we might become, and who we think we might become" (2011, p. 550).

As a case in point, Ess (2010) discusses how changes in literacy interact with our notion of selfhood. Ess describes how our sense of the self as an autonomous individual is related to print culture and both underlies and requires modern liberal democracy. As our culture shifts, with modern ICTs, into what Ong (1982) calls secondary orality (i.e., a blend of print and oral culture), our sense of self is giving way to a networked, relational or "smeared out" self. Ess worries, along with thinkers such as Postman (1984) and Day (2014), that modern ICTs block out possibilities for critical engagement and thinking-indispensable 
elements of self-care. Even though a privileged elite may still be able to function as autonomous selves in this clime, the masses may only be able to "amuse themselves to death," to use Postman's famous phrase.

Ess (2010) suggests that the best-case scenario for our future is that we will develop a more complex sense of self, which he calls a hybrid self, such that "the skills and abilities of literacy and print will continue to make possible the sort of 'care of self' apparently needed to foster the emergence and sustained presence of a modern self as moral agent" (Ess, 2010, pp. 113-114). This hybrid self entails on one hand a modern-style individual self that Ess calls the virtuous self, which practices privacy, autonomy, skilled judgment, patience, etc. This virtuous self grounds the function of the relational self, which is widely distributed across networked technologies that entail pleasure, convenience, distraction and surveillance. To connect this to Floridi's (2013) conceptualization of selfhood, we can understand this hybridity to sit chiefly at the conscious layer, though Floridi does contend that multi-agent systems can be selves, in which case the biological and cognitive layers are also distributed.

If the alternative is enslavement to ICTs and a total loss of selfhood, we should work to cultivate this hybrid self. Given the inevitability that technology shapes humanity, and that humanity and technology are inextricable from each other, a crucial route for self-construction and self-care is through technology, as mentioned in a seminal paper by Rafael Capurro (1996). What does such self-care look like, practically speaking? For an answer, we can look to the later work of Foucault $(1988,1997)$, in which he turned away from the sociological, historical and political issues for which he is best known, toward questions of selfhood.

Foucault (1988) explored how the Socratic principle of self-care was enacted technologically in Antiquity, through a set of technological practices. According to Foucault, these technologies of the self

permit individuals to effect by their own means or with the help of others a certain number of operations on their own bodies and souls, thoughts, conduct, and way of being, so as to transform themselves in order to attain a certain state of happiness, purity, wisdom, perfection, or immortality. (Foucault, 1988, p. 18)

One example of such technologies were personal notebooks. As Foucault writes, many people-and not only the elite by any means-in Ancient Greece and Rome kept hypomnemata (singular: hypomnema), or notebooks "to collect what one has managed to hear or read, and for a purpose that is nothing less than the shaping of the self" (Foucault, 1997, p. 211). These were fragmentary notebooks, but their result was not merely a collection of disjointed scraps; rather, they contributed to a new whole, along with the writer. According to Foucault, the purpose of keeping hypomnemata was, explicitly, to care for the self. These notebooks are but one example of ancient technological self-care; other examples included letter-writing and meditation. 
Taking a step away from the particulars, the various technologies of the self that Foucault $(1988,1997)$ analyzes seem to share some general principles that make them conducive to self-care:

- bringing oneself out of mundane setting (physically and/or mentally) in order to reflect (i.e., retreating into oneself)

- revisiting the past and imagining the future

- comparison of the self to something outside (external reality, social rules, God, etc.)

- investigation of the interplay between one's private and public lives

- contemplation of the divine as a mirror to view the self

- looking at the mundane details of life

A key aspect of these practices of self-care is that they are hermeneutic, meaning they function through iterative interpretation. Something is written or thought (externalized) and then examined (internalized), and the thoughts that arise are then externalized and internalized again.

On Foucault's account, these practices shifted during the middle ages and gradually faded away; since the 17th century or so, the focus has been on externalization. Thus a millennia-old toolkit for self-care seems to have been forgotten. And if we follow the discussion of Ess (2010), we can conclude that modern ICTs may not be conducive to such hermeneutic reflection. Bakardjieva and Gaden (2012) suggest this is because today's ICTs blend technologies of the self with technologies of production in an unprecedented way, as users' participation (free labor) is commodified and channeled into corporate profits. They make the point that, if contemporary technologies of the self are used uncritically and unreflectively, they may not truly be conducive to self-care. As Marche (2012, para. 38) writes, "Now we are left thinking about who we are all the time, without ever really thinking about who we are."

How can we recoup authentic possibilities for technological self-care? Capurro (1996) gives some indication; for him, ethical ICTs must afford: friendship with other people and beings, choice in the face of oppression, silence in an age of noise, and laughter in spite of fear. Separately, Heim (1998) distills principles for ICT design meant to resolve a perceived conflict between humanity and nature, which he presents in a framework of harmony, respect, purity and serenity. Such accounts, while inspiring, are not concrete, and consequently it is unclear how they could be put into practice. And, in the context of the crisis of meaning and perfectionism, it seems that, over 20 years after Capurro's and Heim's writing, little progress has been made.

Thus, in the following section, a strategy is sketched for learning what it is about certain older technologies that is self-care-conducive and bringing those aspects to advantage into newer technologies. Specifically, the focus will be on two forms of visual self-documentation: the artistic self-portrait and the selfie. 


\section{Selfie-Making and Self-Portraiture}

Documentation has come to be a "necessary cultural technique" over the past century, as described by Briet (1951/2006) and commentated by Day (2006). Modern society has been called a document society; many of our social processes rely on documents, and now it is through these documents that we come to understand reality (Buckland, 2005). Among these documents are ones we create about ourselves, as evidence of some aspect of the self: pictures of our food, records of the places we go and the routes we take, posts about our joys and travails, photos of our faces... Many have commented that today, "we're living to document our lives" (Fischetti, 2014, para. 5).

Of all the genres of self-documentation, the selfie is particularly notable. Over the past decade or so, it has become ubiquitous. For the uninitiated, the Oxford English Dictionary defines selfie as a self-portrait made with a smartphone camera (Selfie, 2016). Evidence of the importance of the selfie abounds: Oxford Dictionaries (2013) named selfie the international Word of the Year in 2013, citing a 17,000-percent increase in usage over the previous year. In mid-2016, Google reported that over 24 billion selfies had been uploaded to Google Photos in the prior year (Sabharwal, 2016). The social networking applications Instagram and Snapchat largely facilitate the circulation of selfies; as of September 2018, there are over 358 million posts explicitly tagged as selfie on Instagram.

The selfie has engendered a large corpus of scholarship. In these discussions, it has generally been assumed that the selfie is related to artistic selfportraiture (e.g., Lim, 2017; Mirzoeff, 2015; Rettberg, 2014). In the view of Mirzoeff (2015, p. 31), the selfie "expresses, develops, expands and intensifies the long history of the self-portrait." Mirzoeff sees the selfie as a digital, networked outgrowth of this artistic tradition. This seems to be the popular opinion, to the extent that, for example, Rembrandt's self-portraits have been described as selfies (e.g., Sooke, 2014). More recently, the Philadelphia Office of Arts, Culture and the Creative Economy presented the exhibit Veterans Empowered Through Art: The Six Week Selfie Project (Huynh, 2017), which involved museum tours and workshops and included sketches, complete self-portraits, poetry and personal photos-far more than the term selfie implies.

Conflation and confusion notwithstanding, it seems that selfies and selfportraits are quite different. In my doctoral research, I conducted a wide-ranging review of the literature on selfies and self-portraits; due to space constraints, the findings of this review must be summarized here only very briefly. A review of the relevant scholarship suggests that selfies:

- do not require technical skills (Lim, 2017; Lüders, Prøitz \& Rasmussen, 2010; Peek, 2014; Saltz, 2014)

- emphasize the present moment (Peek, 2014; Saltz, 2014)

- emphasize external appearances (Wendt, 2014; but see Qiu, Lu, Yang, Qu \& Zhu, 2015) 
- manifest a networked sense of self (Levin, 2016; Lüders et al., 2010; Mirzoeff, 2015; Rettberg, 2014; Rubinstein, 2016; Wendt, 2016)

- are rooted in sharing, communication and consumerism (Frosh, 2015; Lim, 2017; Mirzoeff, 2015)

- may be motivated by narcissism and exhibitionism (Fox \& Rooney, 2015; Lee \& Sung, 2016; Maddox, 2017; Miltner \& Baym, 2015; but see Warfield, 2014)

The self-portrait, according to the scholarship, is opposed to the selfie along all these dimensions. Self-portraiture does require training and expertise; selfportraits are meant to be timeless, integrating the past, present and future, and they must be created over a stretch of time; they emphasize the artist's inner life rather than external appearance; they manifest the individualist sense of self; they are relatively seldom shared or exhibited (and to the extent that they are communicative, the communication is substantive rather than phatic); and they are intrinsically motivated (Cumming, 2009; Freeland, 2010; Hall, 2014; Maes, 2015; Woods-Marsden, 1998). Additionally, whereas selfies are bound to smartphone technology (camera and web-sharing capabilities), self-portraits may be done in any medium or style.

This comparison, admittedly, has been simplified. In some cases, the distinction between selfies and self-portraits is not so clear. Even if the paradigmatic selfie can (uncharitably) be called meaningless and mindless, there are surely cases in which selfies are personally meaningful sites for self-authoring, and where they involve effort, drawing out and taking time (see Bae-Dimitriadis, 2015; Berlatsky, 2013; Brager, 2017; Ehlin, 2015; Murray, 2015; Warfield, 2014). But it would seem, philosophically speaking, that such "selfies" ought not to be considered selfies, but rather truly self-portraits.

What is important for the present discussion is the self-portrait's and/or selfie's capacity for self-care. The scholarship on self-portraits shows that selfportraits have served as technologies of self-care at least since the 15th century. Empirical accounts have shown self-portraiture to be successful in art therapy (Alter Muri, 2007) and conducive to building understanding of the self and constructing that very self (Gorichanaz, 2018). Some of the features that seem to afford this are the time and hermeneutic reflection it takes to create a selfportrait.

If, as Ess (2010) and others suggest, we are bearing witness to the growing dominance of a relational sense of self, then the selfie is a paragon of that emergence. It also epitomizes the trend toward perfectionism, as social media users seek to present themselves as flawlessly as possible. On the other hand, the self-portrait is a technology of care associated with the virtuous self, and the construction of the self. Moreover, art in general and self-portraiture in particular are ways to practice free expression in a world where, more and more, selves are constrained and defined by given standardized possibilities in information systems. 
Thus, if our best hope for the future is a hybrid self (Ess, 2010), then perhaps there is a place for both selfies and self-portraits in our toolbox of selfconstruction. To be sure, selfies are created far and away much more frequently than are self-portraits. Self-portraits are in the purview of a privileged few. But there would seem to be an opportunity to democratize self-portraiture in a way that preserves its capacity for virtuous self-care. To be sure, the selfie has been lauded as a democratized form of self-portraiture, but it does not seem to have (always) preserved this aspect of the self-portrait.

What might such a democratization look like? This question constitutes an important path for future research to explore. For now, there are some kernels of answers. One area lies in work around Slow Art, which brings the Slow movement into the art world (Reed, 2017). Slow Art seeks to engage the public more deeply with art objects. Perhaps similar tactics could be used to engage selfie-makers more deeply in their practice-a kind of Slow Selfie. Next, the work of Winnemöller and his colleagues at Adobe Research seeks to automate aspects of the creative process while still leaving space for the user to experience agency and creativity; examples include the How2Sketch (Hennessey et al., 2017), Interactive Vectorization (Xie et al., 2017) and PaintCan (http://www.paintcanapp.com) systems. Similar systems could be devised for smartphone self-portraiture. Lastly, library and museum professionals as well as educators of all stripes could guide their constituents in the creation of their own self-portraits, with an emphasis on the self-care aspects, rather than, necessarily, artistic merit. What all these efforts would share is a pivot away from perfectionism and toward constructionism of self.

\section{Conclusion}

An underlying theme of this paper is that technology development has uncritically followed can rather than should for the past few decades, the deleterious effects of which are starting to show. Fortunately, technologists, scholars and the public are beginning to take note. For instance, the Center for Humane Technology (http://humanetech.com) has recently been founded, bringing together technologists in the mission of ethical technological development; information ethics is a topic of growing academic interest, as evidenced by recent conferences in the information and computer sciences; and such issues have become topics of public interest following major scandals of privacy and misinformation.

The question of the self has not been connected to these issues, and nor has it been much discussed in information ethics generally. Thus, the present paper has resurfaced questions of selfhood and meaning in the context of perfectionism and ICTs. Today, the self can be fruitfully understood as an agent within the ontic trust to which we all belong. Technology development should proceed with this in mind, leveraging opportunities for mutual respect and 
construction. The discussion of selfies and self-portraits in this paper is but one example of a technology for self-care that has gone astray but can be brought back into the fold of meaningfulness. Self-portraiture is a meaningful way to contribute to the ontic trust, and in the future selfie-making could be as well. 


\section{References}

Alter Muri, S. (2007), "Beyond the face: art therapy and self-portraiture", The Arts in Psychotherapy, Vol. 34 No. 4, pp. 331-339.

Bae-Dimitriadis, M. (2015), “Performing 'planned authenticity': diasporic Korean girls' selfphotographic play", Studies in Art Education, Vol. 56 No. 4, pp. 327-340.

Baer, D. (2017, June 16), "Here's the profound psychological shift that frees people from perfectionism", Thrive Global, available at https://medium.com/thrive-global/heres-theprofound-psychological-shift-that-frees-people-from-perfectionism-290dc09ad73 (accessed 24 October 2018)

Bakardjieva, M. and Gaden, G. (2012), "Web 2.0 technologies of the self”, Philosophy $\&$ Technology, Vol. 25 No. 3, pp. 399-413.

Baumeister, R.F. (1991), Meanings of Life, Guilford Press, New York, NY.

Baumeister, R.F. (2005), The Cultural Animal: Human Nature, Meaning, and Social Life, Oxford University Press, New York, NY.

Bawden, D. and Robinson, L. (2018), "Curating the infosphere: Luciano Floridi's philosophy of information as the foundation for library and information science", Journal of Documentation, Vol. 74 No. 1, pp. 2-17.

Berlatsky, N. (2013), "Selfies are art", The Atlantic, available at https:// www.theatlantic.com/ entertainment/archive/2013/11/selfies-are-art/281772/ (accessed 4 September 2018)

Brager, J.B. (2017), "On the ethics of looking”, In Kuntsman, A. (Ed.), Selfie Citizenship, Springer International, Cham, Switzerland, pp. 161-163.

Briet, S. (1951/2006), "What is documentation?", in Day, R.E., Martinet, L. and Anghelescu, H.G.B. (Eds. \& Trans.), What is Documentation? English Translation of the Classic French Text, Scarecrow Press, Lanham, MD, pp. 9-46.

Buckland, M.K. (2005), "Information schools: a monk, library science, and the information age", in Hauke, P. (Ed.), Bibliothekswissenschaft-quo vadis?, Munich: K. G. Saur, Munich, pp. 19-32.

Capurro, R. (1996), "Information technology and technologies of the self", Journal of Information Ethics, Vol. 5 No. 2, pp. 19-28.

Centers for Disease Control and Prevention. (2012), "QuickStats: prevalence of current depression among persons aged $\geq 12$ years, by age group and sex", Morbidity and Mortality Weekly Report, Vol. 60 No. 51, available at https://www.cdc.gov/mmwr/preview/mmwrhtml/ mm6051a7.htm (accessed 4 September 2018)

Cumming, L. (2009), A Face to the World: On Self-Portraits, HarperPress, London, UK.

Curran, T. and Hill, A.P. (2018), "Perfectionism is increasing over time: a meta- analysis of birth cohort differences from 1989 to 2016", Psychological Bulletin, Online First, available at http://dx.doi.org/10.1037/bul0000138 (accessed 4 September 2018)

Day, R.E. (2006), “'A necessity of our time': documentation as 'cultural technique' in What is Documentation?”, in Day, R.E., Martinet, L. and Anghelescu, H.G.B. (Eds. \& Trans.), What is Documentation? English Translation of the Classic French Text, Scarecrow Press, Lanham, MD, pp. 47-63.

Day, R.E. (2014), Indexing It All: the Subject in the Age of Documentation, Information, and Data, MIT Press, Cambridge, MA.

Ehlin, L. (2015), “The subversive selfie: redefining the mediated subject”, Clothing Cultures, Vol. 2 No. 1, pp. 73-89.

Erfani, S.S. and Abedin, B. (2018), "Impacts of the use of social network sites on users' psychological well-being: a systematic review", Journal of the Association for Information Science and Technology, Vol. 69 No. 7, pp. 900-912. 
Ess, C. (2010), “The embodied self in a digital age”, Nordicom Information, Vol. 32 Nos. 2-3, pp. 105118.

Fischetti, M. (2014), "How \#selfie culture is changing our lives", Scientific American, 19 August, available at https://blogs.scientificamerican.com/observations/how-selfie-culture-ischanging-our-lives (accessed 4 September 2018)

Flett, G.L. and Hewitt, P.L. (2002), Perfectionism: Theory, Research, and Treatment, American Psychological Association, Washington, DC.

Floridi L. (2004), "Afterword. LIS as applied philosophy of information: a reappraisal", Library Trends, Vol. 53 No. 3, pp. 658-685.

Floridi, L. (2011), “The informational nature of personal identity", Minds and Machines, Vol. 21 No. 4, pp. 549-566.

Floridi, L. (2013), The Ethics of Information, Oxford University Press, Oxford, UK.

Foucault, M. (1988), “Technologies of the Self”, in Martin, L.H., Gutman H. and Hutton P.H. (Eds.), Technologies of the Self, University of Massachusetts Press, Amherst, pp. 16-49.

Foucault, M. (1997), Ethics: Subjectivity and Truth (The Essential Works of Foucault, Volume 1, 19541984) (P. Rabinow, Ed. \& R. Hurley, Trans.), The New Press, New York, NY.

Fox, J. and Rooney, M. (2015), “The dark triad and trait self-objectification as predictors of men's use and self-presentation behaviors on social networking sites", Personality and Individual Differences, Vol. 76, pp. 161-165.

Frankl, V.E. (2006), Man's Search for Meaning, Beacon, Boston, MA.

Freeland, C. (2010), Portraits and Persons: A Philosophical Inquiry, Oxford University Press, Oxford, UK.

Frosh, P. (2015), "Selfies - the gestural image: the selfie, photography theory, and kinesthetic sociability", International Journal of Communication, Vol. 9 No. 22, pp. 1607-1628.

Fyffe, R. (2015), “The value of information: Normativity, epistemology, and LIS in Luciano Floridi", Portal: Libraries and the Academy, Vol. 15 No. 2, pp. 267-286.

García-Alandete, J. (2015), “Does Meaning in Life Predict Psychological Well-Being?”, The European Journal of Counselling Psychology, Vol. 3 No. 2, pp. 89-98.

Gorichanaz, T. (2018), "Art and everyday information behavior: Sources of understanding", paper presented at Association for Information Science and Technology Annual Meeting, 11-13 November, Vancouver, Canada.

Hadot, P. (1995), Philosophy as a Way of Life (A. I. Davidson, Ed. \& M. Chase, Trans.), Blackwell, Malden, MA.

Hall, J. (2014), The Self-Portrait: a Cultural History, Thames \& Hudson, London, UK.

Hamachek, D.E. (1978), "Psychodynamics of normal and neurotic perfectionism", Psychology, Vol. 15, pp. 27-33.

Heidegger, M. (1927/2010), Being and Time, (Trans. by J. Staumbaugh and ed. by D.J. Schmidt), State University of New York Press, Albany, NY.

Heim, M. (1998), "Virtual Reality and the Tea Ceremony", in Beckmann, J. (Ed.), The Virtual Dimension: Architecture, Representation, and Crash Culture, Princeton Architectural Press, Princeton, NJ, pp. 156-177.

Hellmann, E. (2016), Keeping Up Appearances: Perfectionism and Perfectionistic Self-Presentation on Social Media (Unpublished Honors Thesis). Depauw University, Greencastle, IN, available at https://scholarship.depauw.edu/studentresearch/50 (accessed 4 September 2018)

Hennessey, J.W., Liu, H., Winnemöller, H., Dontcheva, M. and Mitra, N.J. (2017), "How2Sketch: Generating Easy-To-Follow Tutorials for Sketching 3D Objects", paper presented at the Symposium on Interactive 3D Graphics and Games, 25-27 February, San Francisco, CA.

Hewitt, P.L., Flett, G.L. and Mikail, S.F. (2017), Perfectionism: A Relational Approach to Conceptualization, Assessment, and Treatment, Guilford Press, New York, NY. 
Hobbes, T. (1651), Leviathan, Andrew Crooke, London, UK, available at https:// socialsciences.mcmaster.ca/econ/ugcm/3ll3/hobbes/Leviathan.pdf (accessed 24 October 2018)

Huynh, T. (2017), "Veterans empowered through art: The Six Week Selfie Project", available at http://creativephl.org/vet_art/ (accessed 4 September 2018)

Jonas, H. (1984), The Imperative of Responsibility: In Search of an Ethics for the Technological Age, University of Chicago Press, Chicago, IL.

Landau, I. (2018), Finding Meaning in an Imperfect World, Oxford University Press, Oxford, UK.

Lanier, J. (2018), Ten Arguments for Deleting Your Social Media Accounts Right Now, Henry Holt, New York, NY.

Lee, J.A. and Sung, Y. (2016), "Hide-and-seek: narcissism and 'selfie'-related behavior", Cyberpsychology, Behavior, and Social Networking, Vol. 19 No. 5, pp. 347-351.

Levin, A. (2016), "The networked self(ie). Codes, nodes and rhizomes", in Bieber, A. (Ed.), Ego Update: a History of the Selfie, Koenig, Berlin, Germany, pp. 96-133.

Lim, W.M. (2017), "Understanding the selfie phenomenon: current insights and future research directions", European Journal of Marketing, Vol. 50 Nos. 9/10, pp. 1773-1788.

Lüders, M., Prøitz, L. and Rasmussen, T. (2010), "Emerging personal media genres", New Media \& Society, Vol. 12 No. 6, pp. 947-963.

Maddox, J. (2017), “'Guns don't kill people . . . selfies do': Rethinking narcissism as exhibitionism in selfie-related deaths", Critical Studies in Media Communication, Vol. 34 No. 3, pp. 193205.

Maes, H. (2015), “What is a portrait?", British Journal of Aesthetics, Vol. 55 No. 3, pp. 303-322.

Marche, S. (2012), "Is Facebook making us lonely?", The Atlantic, available at https:// www.theatlantic.com/magazine/archive/2012/05/is-facebook-making-us-lonely/308930/ (accessed 4 September 2018)

Mazlish, B. (1993), The Fourth Discontinuity: The Co-Evolution of Humans and Machines, Yale University Press, New Haven, CT.

Miltner, K. and Baym, N. (2015), "The selfie of the year of the selfie: reflections on a media scandal", International Journal of Communication, Vol. 9 No. 22, pp. 1701-1715.

Mirzoeff, N. (2015), How to See the World, Pelican Books, London, UK.

Murphy, S.L., Xu, J., Kochanek, K.D., Curtin, S.C. and Arias, E. (2017), "Deaths: Final data for 2015", National Vital Statistics Report, Vol. 66 No. 6, available at https://www.cdc.gov/nchs/data/ nvsr/nvsr66/nvsr66_06.pdf (accessed 4 September 2018)

Murray, D.C. (2015), "Notes to self: the visual culture of selfies in the age of social media", Consumption Markets \& Culture, Vol. 18 No. 6, pp. 490-516.

Oishi, S. and Diener, E. (2014), "Residents of poor nations have a greater sense of meaning in life than residents of wealthy nations", Psychological Science, Vol. 25 No. 2, pp. 422-430.

Ong, W.J. (1982), Orality and Literacy: the Technologizing of the Word, Methuen \& Co, London, UK.

Oxford Dictionaries (2013), "The Oxford Dictionaries Word of the Year 2013", Oxford Dictionaries Blog, 19 November, available at http://blog.oxforddictionaries.com/press-releases/oxforddictionaries-word-of-the-year-2013/ (accessed 4 September 2018)

Parry, R. (2014), "Ancient Ethical Theory", The Stanford Encyclopedia of Philosophy, available at https://plato.stanford.edu/archives/fall2014/entries/ethics-ancient/ (accessed 4 September 2018)

Peek, H. (2014), "The selfie in the digital age: from social media to sexting", Psychiatric Times, Vol. 31 No. 12 , p. $28 \mathrm{~g}$.

Pentina, I. and Tarafdar, M. (2014), "From 'information' to 'knowing': Exploring the role of social media in contemporary news consumption", Computers in Human Behavior, Vol. 35, pp. 211-223. 
Plato (2002), Five Dialogues: Euthyphro, Apology, Crito, Meno, Phaedo, Hackett, Indianapolis, IN.

Qiu, L., Lu, J., Yang, S., Qu, W. and Zhu, T. (2015), "What does your selfie say about you?", Computers in Human Behavior, Vol. 52, pp. 443-449.

Postman, N. (1984), Amusing Ourselves to Death, Penguin, New York, NY.

Rachel, J. and Rachel, S. (2015), The Elements of Moral Philosophy (8th ed.), McGraw-Hill, New York, NY.

Reed, A. (2017), Slow Art: the Experience of Looking, Sacred Images to James Turrell, University of California Press, Oakland, CA.

Reker G.T. and Wong, P.T.P. (1988), "Aging as an individual process: Toward a theory of personal meaning", in Birren, J.E. and Bengtson, V.L. (Eds.), Emergent Theories of Aging, Springer, New York, NY, pp. 214-246.

Rettberg, J.W. (2014), Seeing Ourselves Through Technology: How We Use Selfies, Blogs and Wearable Devices to See and Shape Ourselves, Palgrave Macmillan, Basingstoke, UK.

Rubinstein, D. (2016), "Gift of the selfie", in Bieber, A. (Ed.), Ego Update: a History of the Selfie, Koenig, Berlin, Germany, pp. 162-176.

Sabharwal, A. (2016), "Google Photos: one year, 200 million users, and a whole lot of selfies", Google Blog, 27 May, available at https://blog.google/products/photos/google-photos-oneyear-200-million/ (accessed 4 September 2018)

Saltz, J. (2014), "At arm's length: a history of the selfie", Vulture, available at http:// www.vulture.com/2014/01/history-of-the-selfie.html (accessed 4 September 2018)

Saunders, J.F. and Eaton, A.A. (2018), "Snaps, selfies, and shares: how three popular social media platforms contribute to the sociocultural model of disordered eating among young women", Cyberpsychology, Behavior, and Social Networking, Vol. 21 No. 6, Online First, available at https://doi.org/10.1089/cyber.2017.0713 (accessed 4 September 2018)

Selfie (2016), OED Online, available at http://oed.com/view/Entry/390063 (accessed 4 September 2018)

Smith, E.E. (2017), The Power of Meaning: Crafting a Life That Matters, Random House, New York, NY.

Smith, M.M., Sherry, S.B., Chen, S., Saklofske, D.H., Mushquash, C., Flett, G.L. and Hewitt, P.L. (2018), "The perniciousness of perfectionism: a meta-analytic review of the perfectionism-suicide relationship", Journal of Personality, Vol. 86 No. 3, pp. 522-542.

Sooke, A. (2014), "Did Rembrandt invent the selfie?", BBC, 9 October, available at http:// www.bbc.com/culture/story/20141009-did-rembrandt-invent-the-selfie (accessed 4 September 2018)

Storr, W. (2018), Selfie: How We Became So Self-Obsessed and What It's Doing to Us, Overlook, New York, NY.

Van der Veer Martens, B. (2017), "New grounds for ontic trust: information objects and LIS", Education for Information, Vol. 33 No. 1, pp. 37-54.

Verduyn, P., Lee, D.S., Park, J., Shablack, H., Orvell, A., Bayer, J., Ybarra, O., Jonides, J. and Kross, E. (2015), "Passive Facebook usage undermines affective well-being: experimental and longitudinal evidence", Journal of Experimental Psychology: General, Vol. 144 No. 2, p. 480.

Walker, S. (2011), The Spirit of Design: Objects, Environment and Meaning, Earthscan, London, UK.

Warfield, K. (2014), "Making selfies/making self: digital subjectivities in the selfie", in Proceedings of the Image Conference, Berlin, October 30th, 2014, available at http://kora.kpu.ca/ facultypub/8/ (accessed 4 September 2018)

Wendt, B. (2014), The Allure of the Selfie: Instagram and the New Self-Portrait, Institute of Network Cultures, Amsterdam, Netherlands.

Wiener, N. (1954), The Human Use of Human Beings: Cybernetics and Society, Houghton Mifflin, New York, NY. 
Woods-Marsden, J. (1998), Renaissance Self-Portraiture: the Visual Construction of Identity and the Social Status of the Artist, Yale University Press, New Haven, CT.

Wright, H.G. (2016), Ontic Ethics, Lexington, Lanham, MD.

Xie, J., Winnemöller, H., Li, W. and Schiller, S. (2017), "Interactive vectorization", in Proceedings of the 2017 CHI Conference on Human Factors in Computing Systems (CHI '17), ACM, New York, NY, pp. 6695-6705. 